\title{
Comparison of Strength, Heart Rate, Oxygen Saturation and Technical Test Values of 12-14 Year Male Tennis Players in Competition Period
}

\author{
Gürhan SUNA ${ }^{1} \&$ Mahmut ALP ${ }^{2}$ \\ ${ }^{1}$ Department of Coaching Education, Süleyman Demirel University, Isparta, Turkey \\ ${ }^{2}$ Department of Physical Education and Sports Education, Süleyman Demirel University, Isparta, Turkey \\ Correspondence: Gürhan SUNA, Department of Coaching Education, Süleyman Demirel University, Isparta, \\ Turkey. E-mail: gurhan_suna@windowslive.com
}

$\begin{array}{ll}\text { Received: October 1, } 2019 & \text { Accepted: November 15, } 2019 \quad \text { Online Published: November 17, } 2019 \\ \text { doi:10.5539/jel.v8n6p187 } & \text { URL: https://doi.org/10.5539/jel.v8n6p187 }\end{array}$

\begin{abstract}
This study seeks to compare and contrast 12 to 14 years old male tennis players in terms of strength, heart rate, oxygen saturation and technical test values. A total of 15 tennis players took part in the study after filling in a parental consent form. The average age, height and weight of the male tennis players were found to be $13.1 \pm$ 1.06 years, $154.07 \pm 5.04 \mathrm{~cm}, 36.5 \pm 3.85 \mathrm{~kg}$ respectively. In comparing of the values, the preliminary test was applied in the first week while the last test was applied in the eighth week, taking anatomical adaptation into consideration. During that period, the players were exposed to a 90-minute training three days a week. Both during the pretest and the last test, the players were exposed to 30 seconds push-up, sit-up, ropeskipping, AOS Technical Test, $\mathrm{SpO} 2$ tests and their heart rates were measured. The values obtained were compared using "paired t test" with a statistical software. The significance level was taken as "p $<0.05$ ". Having compared the results of the first and last tests applied to the players, statistically significant differences were found between push-up, sit-up and ropeskipping rates; AOS technical test values, resting pulse, first set of heart rate values, second set of heart rate values $(\mathrm{p}<0.05)$; however, there was significant difference between the first $\mathrm{SpO}$, first set of hear rate values, second set of heart rates and second set of $\mathrm{SpO} 2$ with regard to the pre- and post-test. It is possible to conclude that the technical trainings applied to the players improved the biomotoric and some of the physiological properties of the players, which, by extension, enhanced the performances.
\end{abstract}

Keywords: tennis, strength, physiological properties, technique

\section{Introduction}

Tennis is a branch of sport which provides health benefits for people of all ages. Playing tennis regularly improves coordination, enhances bone health, physiological, physical and psycho-mental development. Developing a substantial physical fitness is of significance. Having achieved this, young tennis players are now able to do basic and special skills of tennis (Groppel \& Dinubile, 2009).

In order to boost performance or to contribute to motoric development, a scheduled training program must be followed for children's exercises (Pate et al., 2002). Strength development for children begins around the ages of 10 to 12 years and with the emergence of gender differences, it gains pace, which becomes even faster at 13 to 14 years. It is believed that tennis training on a regular basis in addition to strength training in order to reduce possible negative effects on performance special to tennis of the asymmetry appearing on adolescent tennis players' body will also positively affect motoric skills and technical stroke performance (Aktaş et al., 2011). While thinking the nature of tennis play, providing an ideal platform of physical fitness represents a significant challenge in the planning of specific strength and conditioning interventions. Several recent reviews have summarized game physiology and mechanics (Elliott, 2007; Kovacs, 2007), markedly less attention has been afforded to examining subsequent practical applications (Reid \& Schneiker, 2008).

Physiology responses are considered to remain relatively stable throughout matchplay (Fernandes et al., 2006), but are sensitive to changes in rally intensity (Christmass et al., 1993), individual gamestyle (Smekal et al., 2001) and game situation (Reilly \& Palmer, 1993). Tennis has thus been described as an intermittent, non-cyclical anaerobic sport with an aerobic recovery phase, or, an activity commensurate with moderate intensity exercise 
(Bergeron et al., 2001). In addition, heart rate during the game in order to determine how rigorous it is a practical method. Among top tennis players, average heart rate during a game was calculated to be $144.6 \pm 13.2 \mathrm{bpm}$. The significance increase in heart rate may be due to the rigor and intermittency, which is in game's nature (Kovacs, 2007). Scientists stated that the assessment of the cardiovascular and metabolic profiles in tennis includes both acute changes during the course of a match and long-term processes of adaptation due to years of training and match play (König et al., 2001). In some researches, a positive correlation was found between heart rate and match activities during the game (direction change, stroke) (Fernandez-Fernandez et al., 2007); Another study measured the service games during the match because of the intermittent nature of the tennis competition mean CAD 146-157 beats/min, while welcome 140-148 beats in the game/min, beats 139-148 between short rest $/ \mathrm{min}$, while long rest (pitch change) between 108-128 beats/min was determined as (Davey et al., 2003). Based on these information, different tactical behaviors applied in matches change the physiological structure of the game.

In the light of literature within the study, we aim to compare and contrast 12 to 14 years old male tennis players in terms of strength, heart rate, oxygen saturation and technical test values in the light of the data collected from the literature.

\section{Method}

\subsection{Participants}

15 tennis players living in Isparta participated in the study by taking the "Parental Permission Form" and provided that the personal information and findings acquired during and after the study are preserved under the seal of secrecy. We applied the principles outlined in the Declaration of Helsinki. The age, height and weight averages of the male tennis players were found to be $13.1 \pm 1.06$ years, $154.07 \pm 5.04 \mathrm{~cm}, 36.5 \pm 3.85 \mathrm{~kg}$ respectively.

\subsection{Measures}

\subsubsection{Measurement of height}

The heights of the players were measured by using a SECA brand height scale having an accuracy of $0.01 \mathrm{~mm}$ sensitivity. The values were enroled as centimeter $(\mathrm{cm})$.

\subsubsection{Measurement of weight}

The body weights of the players were measured by using a SECA brand weight scale having an accuracy of $0.001 \mathrm{~kg}$ sensitivity. The values were enroled as kilogram $(\mathrm{kg})$.

\subsubsection{Push-Up Test}

The tennis players taking part in the study did push-ups for $30 \mathrm{sec}$ with maximum pace with a cue. The best performance achieved in $30 \mathrm{sec}$ was recorded.

\subsubsection{Sit-Up Test}

The players lie on their backs with knees bend to 90 degrees and with hands on the back of their heads where it attaches to the neck, the elbows pointing to the sides. Then, they place their feet hip distance apart. They try to do as many sit-ups as possible in 30 seconds and "stop" command. The highest score achieved at the end of 30 sec was recorded as the test record.

\subsubsection{Rope Skipping Test}

The players taking part in the study began skipping rope with the "go" command, trying to achieve the best score in $30 \mathrm{sec}$. Again, the best score was recorded as the test record.

\subsubsection{Measurement of Heart Rate (HR)}

Heart rate values were recorded by using the Polar RS-400 (USA) multi-pulse control watch and chest strap. The measurements were done before and after a practice game and during each game interval change.

\subsubsection{Oxygen Saturation (SpO2)}

Oxygen saturation values of the players were taken by using Smart Pulse Oximeter. The measurements were done before and after a practice game and during each game interval change.

\subsubsection{AOS Performance Technical Test}

Evaluations were done on technical shots performed by the players. Within this context, depth evaluation of groundstrokes, accuracy evaluation of groundstrokes, evaluation of volleys and serves. 


\subsection{Procedures}

In comparison of the values, the preliminary test was applied in the first week while the last test was applied in the eighth week, taking anatomical adaptation into consideration. During that period, the players were exposed to a 90-minute training three days a week. The measurements for all the players were carried out between $4 \mathrm{pm}$ and $6 \mathrm{pm}$.

\subsubsection{Training Program}

Table 1. 8-week training program (1-4 Weeks)

\begin{tabular}{|c|c|c|c|}
\hline WEEK & MONDAY & WEDNESDAY & FRIDAY \\
\hline 1 & $\begin{array}{l}-\quad 20 \text { min warm-up } \\
-\quad 55 \text { min technical strokes } \\
\text { (Forehand- Backhand) } \\
\text { - } \quad 15 \text { min cool down }\end{array}$ & $\begin{array}{ll}\text { - } & 20 \text { min warm-up } \\
\text { - } & 60 \text { min strength trainings } \\
\circ & 3 \times 10 \text { push-ups } \\
\circ & 3 \times 10 \text { sit-ups } \\
\circ & 3 \times 25 \text { rope skipping } \\
\text { - } & 10 \text { min cool down } \\
\end{array}$ & $\begin{array}{l}\text { - } \quad 20 \text { min warm-up } \\
\text { - } \quad 60 \text { min technical strokes } \\
\text { (Forehand- Backhand) } \\
\text { - } \quad 10 \text { min cool down }\end{array}$ \\
\hline 2 & $\begin{array}{ll} & 20 \text { min warm-up } \\
\text { - } & 60 \text { min drills developing technique } \\
\text { - } & 10 \text { min cool down }\end{array}$ & $\begin{array}{ll}- & 20 \text { min warm-up } \\
- & 60 \text { min conditional trainings } \\
\circ & \text { Ladder exercises }(20 \times 4) \\
\circ & 5 \text { min rest } \\
\circ & \text { Jump trainings ( } 8 \text { barriers, } 2 \times 2) \\
\circ & 5 \text { min rest } \\
\text { - } & 10 \text { min cool down } \\
\end{array}$ & $\begin{array}{l}\text { - } \quad 20 \text { min warm-up } \\
\text { - } \quad 60 \text { min drills developing } \\
\text { technique } \\
\text { - } \quad 10 \text { min cool down }\end{array}$ \\
\hline 3 & $\begin{array}{l}\text { - } \quad 20 \text { min warm-up } \\
\text { - } \quad 60 \text { min technical strokes } \\
\text { (Forehand- Backhand) } \\
\text { - } \quad 10 \text { min cool down }\end{array}$ & $\begin{array}{ll}\text { - } & 20 \text { min warm-up } \\
\text { - } & 60 \text { min strength and velocity trainings } \\
\circ & 3 \times 10 \text { push-ups } \\
\circ & 2 \text { min rest } \\
\circ & 3 \times 10 \text { sit-ups } \\
\circ & 2 \text { min rest } \\
\circ & 2 \times 230 \mathrm{~m} \text { sprint, } 10 \mathrm{~m} \text { slow } \\
\circ & 5 \text { min rest between sets } \\
\text { - } & 10 \text { min cool down }\end{array}$ & $\begin{array}{ll}- & 20 \text { min warm-up } \\
- & 60 \text { min technical strokes } \\
\text { (Forehand- Backhand-Service) } \\
\text { - } \quad 10 \text { min cool down }\end{array}$ \\
\hline 4 & $\begin{array}{l}\text { - } \quad 20 \text { min warm-up } \\
\text { - } \quad 40 \text { min technical strokes } \\
\text { (Forehand- Backhand-Service) } \\
\text { - } \quad 20 \text { min minicourt rally } \\
\text { - } \quad 10 \text { min cool down }\end{array}$ & $\begin{array}{ll}- & 20 \text { min warm-up } \\
- & 60 \text { min strength and velocity trainings } \\
\circ & \text { Rope skipping }(4 \times 60) \\
\circ & 3 \text { min rest between sets } \\
\circ & 1 \mathrm{~kg} \mathrm{x6} \text { throwing medicine ball to } \\
\text { backward } \\
\circ \quad 2 \text { min rest between sets } \\
\circ \\
\text { with medicine balls } \\
\text { w } 6 \text { forehand and backhand strokes } \\
\text { - } \\
2 \text { min rest between sets } \\
10 \text { min cool down }\end{array}$ & $\begin{array}{l}\text { - } \quad 20 \text { min warm-up } \\
\text { - } \quad 40 \text { min technical strokes } \\
\text { (Forehand- } \\
\text { Backhand-Service-Spike) } \\
\text { - } \quad 20 \text { min minicourt rally } \\
\text { - } \quad 10 \text { min cool down }\end{array}$ \\
\hline
\end{tabular}


Table 2. 8-week training program (5-8 Weeks)

\begin{tabular}{|c|c|c|c|}
\hline WEEK & MONDAY & WEDNESDAY & FRIDAY \\
\hline 5 & $\begin{array}{l}\text { - } \quad 20 \text { min warm-up } \\
\text { - } \quad 60 \text { min drills developing technique } \\
\text { - } \quad 10 \text { min cool down }\end{array}$ & $\begin{array}{ll}- & 20 \text { min warm-up } \\
\text { - } & 60 \text { min quickness trainings } \\
\circ & 3 \times 2 \text { ladder foot works } \\
\circ & 5 \text { min rest between sets } \\
\circ & 3 \times 5 \text { split-step works } \\
\circ & 5 \text { min rest between sets } \\
\text { - } & 10 \text { min cool down } \\
\end{array}$ & $\begin{array}{ll}- & 20 \mathrm{~min} \text { warm-up } \\
\text { - } & 60 \mathrm{~min} \text { rally at baseline } \\
\text { - } & 10 \mathrm{~min} \text { cool down }\end{array}$ \\
\hline 6 & $\begin{array}{ll}- & 20 \text { min warm-up } \\
- & 40 \text { min technical strokes } \\
\text { (Forehand- Backhand-Service) } \\
\text { - } \quad 20 \text { min baseline rally } \\
\text { - } \quad 10 \text { min cool down }\end{array}$ & $\begin{array}{ll}- & 20 \text { min warm-up } \\
\text { - } & 60 \text { min quickness trainings } \\
\circ & 2 \times 3 \text { sprint work } \\
\circ & 5 \text { min rest between sets } \\
\circ & 3 \times 100 \text { Rope skipping } \\
\circ & 5 \text { min rest between sets } \\
\text { - } & 10 \text { min cool down } \\
\end{array}$ & $\begin{array}{l}\text { - } \quad 20 \text { min warm-up } \\
\text { - } \quad 40 \text { min technical strokes } \\
\text { (Forehand- } \\
\text { Backhand-Service-Spike) } \\
\text { - } \quad 20 \text { min baseline rally } \\
\text { - } \quad 10 \text { min cool down }\end{array}$ \\
\hline 7 & $\begin{array}{l}\text { - } \quad 20 \text { min warm-up } \\
\text { - } \quad 40 \text { min technical strokes } \\
\text { (Forehand- Backhand-Service) } \\
\text { - } \quad 20 \text { min baseline rally } \\
\text { - } \quad 10 \text { min cool down }\end{array}$ & $\begin{array}{ll}\text { - } & 20 \text { min warm-up } \\
- & 60 \text { min quickness trainings } \\
\circ & 3 \times 2 \text { ladder foot works } \\
\circ & 6 \text { min rest between sets } \\
\circ & 4 \times 20 \text { Forehand-backhand work with } \\
\text { theraband } \\
\circ \quad 5 \text { min rest between sets } \\
\text { - } \quad 10 \text { min cool down }\end{array}$ & $\begin{array}{l}\text { - } \quad 20 \text { min warm-up } \\
\text { - } \quad 40 \text { min technical strokes } \\
\text { (Forehand- } \\
\text { Backhand-Service-Spike) } \\
\text { - } \quad 20 \text { min baseline rally } \\
\text { - } \quad 10 \text { min cool down }\end{array}$ \\
\hline 8 & $\begin{array}{ll}\text { - } & 20 \text { min warm-up } \\
\text { - } & \text { Match } \\
\text { - } & 10 \text { min cool down }\end{array}$ & $\begin{array}{ll}- & 20 \text { min warm-up } \\
\text { - } & 60 \text { min quickness trainings } \\
\circ & 3 \times 2 \text { ladder foot works } \\
\circ & 5 \text { min rest between sets } \\
\circ & 3 \times 5 \text { split-step works } \\
\circ & 5 \text { min rest between sets } \\
10 & \text { min cool down } \\
\end{array}$ & $\begin{array}{ll}\text { - } & 20 \text { min warm-up } \\
\text { - } & \text { Match } \\
\text { - } & 10 \text { min cool down }\end{array}$ \\
\hline
\end{tabular}

\subsection{Statistical Analysis}

Statistical Package Program was used for analyzing of the data. "Shapiro-Wilk" Test was used in order to determine whether datas show normal distribution or not and the results were the datas showed normal distribution. "Paired $\boldsymbol{t}$-Test" and "Descriptive Statistics" were used for comparison. The results were evaluated according to " $\mathrm{p}<0.05$ " significance level.

\section{Findings}

Table 3. Paired $t$ test's results of strength test averages

\begin{tabular}{llllll}
\hline & Test Sequence & Mean & SD & t & p \\
\hline Push-up (piece) & Pre-Test & 28.25 & 5.85 & -22.69 & $\mathbf{. 0 0 0}$ \\
& Post-Test & 33.38 & 5.53 & & \\
Sit-up (piece) & Pre-Test & 20.5 & 4.11 & -13.56 & $\mathbf{. 0 0 0}$ \\
\multirow{2}{*}{ Rope Skipping (piece) } & Post-Test & 24.75 & 3.37 & & \\
& Pre-Test & 62.5 & 8.94 & -6.42 & $\mathbf{. 0 0 0}$ \\
& Post-Test & 69.88 & 8.69 & & \\
\hline
\end{tabular}

Table 3 shows the results of strength test averages. According to the Table 3, mean of push-up in pre-test $28.25 \pm$ 5.85 , in post-test $33.38 \pm 5.53$ pieces; mean of sit-up in pre-test $20.5 \pm 4.11$, in post-test $24.75 \pm 3.37$ pieces; mean of rope skipping in pre-test $62.5 \pm 8.94$, in post-test $69.88 \pm 8.69$ pieces was calculated. Results of Paired $t$ Test, statistically significant differences were found $(p<0.05)$. 
Table 4. Paired t test's results of heart rate, oxygen saturation test averages

\begin{tabular}{llllll}
\hline & Test Sequence & Mean & SD & t & p \\
\hline Resting HR & Pre-Test & 94.88 & 9.91 & 3.92 & $\mathbf{. 0 1 0}$ \\
& Post-Test & 91.25 & 7.91 & & \\
SpO2 & Pre-Test & 96.13 & 1.64 & 0.55 & .600 \\
& Post-Test & 96 & 1.31 & & \\
$\mathbf{1}^{\text {st }}$ set of SpO2 & Pre-Test & 95.38 & 2.83 & 1.53 & .170 \\
& Post-Test & 94.88 & 2.53 & & \\
$\mathbf{1}^{\text {st }}$ set of HR & Pre-Test & 121.75 & 29.5 & 4.15 & $\mathbf{. 0 0 0}$ \\
& Post-Test & 103.88 & 19.21 & & \\
$\mathbf{2}^{\text {nd }}$ set of SpO2 & Pre-Test & 96.13 & 2.47 & 1.43 & .200 \\
& Post-Test & 95.75 & 1.9 & & \\
$\mathbf{2}^{\text {nd }}$ set of HR & Pre-Test & 157 & 12.06 & 10.23 & $\mathbf{. 0 0 0}$ \\
& Post-Test & 146.88 & 11.99 & & \\
\hline
\end{tabular}

Table 4 shows the Paired t Test's results of heart rate and oxygen saturation tests. Differences were found significant in resting, 1 st and 2 nd set of heart rate $(p<0.05)$, while there were no differences in all $\mathrm{SpO} 2$ values $(\mathrm{p}>0.05)$.

Table 5. Paired t test's results of technical skill test averages

\begin{tabular}{llllll}
\hline Technical Skill Test & Test Sequence & Mean & SD & t & p \\
\hline AOS Test (score) & Pre-Test & 96.25 & 10.31 & -22.48 & $\mathbf{. 0 0 0}$ \\
& Post-Test & 112 & 11.5 & & \\
\hline
\end{tabular}

Table 5 shows the results of technical skill test averages. According to the Table 5, mean of AOS pre-test $96.25 \pm$ 10.31, post-test $112 \pm 11.5$ scores. Results of Paired t Test, statistically significant differences were found $(\mathrm{p}<$ $0.05)$.

\section{Discussion}

Strength is of utmost importance for a tennis player to be able to display their utmost performance. In tennis, while the lower extremity muscular force helps to reach the ball in the possible shortest time and to be in the right position, the upper extremity muscular force plays a significant role in hitting the ball fast and hard during the game (Chu, 1995).

At the end of the study, while pre-training values were found to be $28.25 \pm 5.85$ for push-up, $20.5 \pm 4.11$ for sit-up, $62.5 \pm 8.94$ for ropeskipping, they were $33.38 \pm 5.53,24.75 \pm 3.37$ and $69.88 \pm 8.69$ respectively. Statistically significant differences were found between pre-training and after training values $(\mathrm{p}<0.05)$.

In Erim's study, which was conducted in 2006, the pre training sit-up value for the experimental group was $60 \pm$ 1.65 and $27.80 \pm 2.25$ for the control group and the after training sit-up value was found to be $27.60 \pm 1.58$ for the experimental group while it was $27.90 \pm 3.03$ for the control group. In a study of Kızılakşam (2006), a group of 12 to 14 years old students were participants. While some of the students were playing sports actively, others were not. In the study, in which eurofit test battery application results were compared, average sit-up figures were calculated to be $23.96 \pm 5.68$. The sit-up values found in this study are close to the ones found in our study.

Behdari (2011) studied the skill levels specific to table tennis and physical profiles of a group of 9 to 12-year-old male table tennis players. In the study, the push-up averages for group $A(n=12)$ was $17.67 \pm 2.64,16.30 \pm 3.67$ for group B $(n=47)$, and $15.64 \pm 2.73$ for group C $(n=53)$. Y1ldiz (2007) determined push-up average as 10.11 \pm 7.91 for 12-year-old male players in a study in which she did research on the effects of quick power exercises on some motoric properties of a group of 12 to 14 years old table tennis players. The findings determined in this study show similarity to the ones in our study. The fact that values found in our study are higher may be due to the fact those participants in our study did more exercise. Turna et al. (2019) defined that different strength protocols could improve the maximal strength such as sit-up, push-up.

We think that our ropeskipping values will be taken as a reference in future studies because we were not able to find any information or figures with regard to ropeskipping in the literature.

Oxygen saturation is known as oxygen saturation, which means the lack of oxygen in the breathing air, the decrease in respiratory efficacy due to muscular diseases, the lack of air intake into the lungs, the insufficiency 
of tissue oxygenation which is a factor of respiratory problems due to the decrease in airway resistance. It is known that oxygen saturation of arterial blood hemoglobin is of vital importance to players (Özdal et al., 2014).

When SPO2 and pulse values of athletes were compared; in the pre-test, it was measured that the resting pulse was $94.88 \pm 9.91$ beats/min, SPO2 $96.13 \pm 1.64 \%$, 1st Set SPO2 $95.38 \pm 2.83 \%$, 1st Set Heart Rate $121.75 \pm$ 29.5 beats/min, 2nd Set SPO2 $96.13 \pm 2.47 \%$, and the 2nd Set Heart Rate was $157 \pm 12.06$ beats/min, and in the post-test, it was measured that the resting pulse was $91.25 \pm 7.91$ beats/min, SPO2 $96 \pm 1.31 \%$, 1 st Set SPO2 $94.88 \pm 2.53 \%$, 1 st Set Heart Rate $103.88 \pm 19.21$ beats/min, 2nd Set SPO2 $95.75 \pm 1.9 \%$, and the 2nd Set Heart Rate was $146.88 \pm 11.99$ beats/min. In comparison of SPO2, 1st set heart rate and 2nd set SPO2 pre and post tests of the sportsmen it was determined that there was no significant difference $(p>0.05)$, yet there was a statistically significant difference between pre and post test of resting heart rate, 1 st set heart rate and 2 nd set heart rate $(\mathrm{p}<0.05)$.

In their study where they examined the Effect of vitamin E on antioxidant and oxidant in football players, Saritaş et al. (2013) found it to be $97.60 \pm 0.32 \%$ before the training, and $97.13 \pm 0.38 \%$ after the training. In the studies of Özdal et al. (2014) on the effect of aerobic training on arterial hemoglobin oxygen saturation, when the pre-test and post-test data of the experimental group is examined; $\mathrm{SpO} 2$ increased from $97.23 \pm 0.93$ percent to $97.85 \pm 0.88$ percent and as a result of statistical analysis, $p$ level significance was found between $\mathrm{T} 1$ and $\mathrm{T} 2(\mathrm{p}=$ 0.032). When the pre-test and post-test data of the experimental group in the same study is examined; SpO2 increased from $96.58 \pm 0.89$ percent to $96.96 \pm 0.64$ percent and as a result of statistical analysis, $\mathrm{p}<0.05$ level significance was found between T1 and T2 $(\mathrm{p}=0.044)$. They think that this significance is caused by the development of respiratory muscles due to aerobic exercise, increased respiratory volume, ensuring proper ventilation perfusion rate, myocardial hypertrophy, and increased cardiac oxygen content (cao2) as a result of increased cardiac output and increased blood hemoglobin count due to exercise. There is a similarity between these values and our values. Furthermore, since studies on SPO2 values of tennis players cannot be found in the literature, our study will shed light on future studies on oxygen saturation. Işıldak and Kumartaşlı (2018) stated in their study that there were positive improvements in pre and post heart rates of athletes. Turna et al. (2017) also found statistically significant differences in pre and post test of heart rates. They said that positive improvements of heart rate depended on intensive and sprint trainings.

AOS technical pretest averages were found to be $96.25 \pm 10.31$ while after test average values were determined as $112 \pm 11.5$. A significant difference was determined between the pre test and after test averages $(p<0.05)$. In a study by Suna (2017), International Tennis Number test (ITN) was used in order to carry out tennis technique measurements of the players. In our study, ITN technical pretest measurements were found to be $124.3 \pm 22.6$ and after test measurements were found to be $193.6 \pm 20.5$. A significant difference was determined between ITN technical pretest and after test measurements $(\mathrm{p}<0.05)$. The fact that ITN technical test values were higher in that study compared to our study may be due to the fact that a different training model was applied and the players were of higher ages.

Özcan, in a similar study conducted in 2011, divided the players into two groups. He gave tennis training to both groups but while one group was trained through inductive method the other was trained through deductive method. ITN test, which we also used in our study, was used in the study in order to determine the players' development. At the end of the study, it was observed that there were significant differences (improvement) between both groups' ITN pretest and after test values (Özcan 2011).

\section{Conclusion}

As a result, according to the findings obtained in our study, it was determined that the technical training program applied throughout the season had a positive effect on the strength, technique, heart rate and oxygen saturation values of the tennis players. Our study shows that technical trainings during the season in tennis, where frequent tournaments are held continuously without conditional trainings, also improve some conditional characteristics of athletes. The reason for this can be said that tennis players exert more physical, physiological, conditional and technical efforts in the competition than the training due to the risk of losing points. The findings of our study may have a direct effect on the preparation of a training program for long-term improvement in tennis with such competition variability. It is also believed that our study will serve as a reference source for future studies and will shed light on sports scientists and coaches accordingly.

\section{References}

Acartürk, E. (2009). KOAH hastalarındaki oksijen satürasyonunun pulse oksimetre ile tespitinin arter kan gazı tetkiki ile korelasyonu ve bu korelasyonu etkileyen faktörler. Uzmanlık Tezi, Süreyyapaşa Gögüs Kalp ve Damar Hastalıkları Eğitim ve Araştırma Hastanesi, İstanbul. 
Aktaş, F., Akkuş, H., Harbili, E., \& Harbili, S. (2011). Kuvvet antrenmanının 12-14 yaş grubu erkek tenisçilerin bazı motorik özelliklerine etkisi. Niğde Üniversitesi Beden Ĕ̆itimi ve Spor Bilimleri Dergisi, 1, 5.

Behdari, R. (2011). 9-12 yaş erkek masa tenisi sporcularının branşa özgü yetenek düzeyleri ve fiziksel profillerinin araştırılması. Gazi Üniversitesi Eğitim Bilimleri Enstitüsü Beden Eğitimi ve Spor Öğretmenliği Anabilim Dalı.

Bergeron, M. F., Maresh, C., Kraemer, W. J., Abraham, A., Conroy, B., \& Gabaree, C. (1991). Tennis: a physiological profile during match play. International Journal of Sports Medicine, 12(05), 474-479. https://doi.org/10.1055/s-2007-1024716

Christmass, M. A., Richmond, S. E., Cable, N. T., \& Hartmann, P. E. (1994). A metabolic characterisation of single tennis. Science and Racket Sports, 3-9.

Chu, D. A. (1995). Power tennis training, Human Kinetics Champaign (pp. 7-15, 33-45).

Davey, P. R., Thorpe, R. D., \& Williams, C. (2003). Simulated tennis matchplay in a controlled environment. Journal of Sports Sciences, 21(6), 459-467. https://doi.org/10.1080/0264041031000101926

Elliott, B. (2006). Biomechanics and tennis. British Journal of Sports Medicine, 40(5), 392-396. https://doi.org/10.1136/bjsm.2005.023150

Erim, V. (2006). 16-18 yaş grubu erkek masa tenisçilerde teknikle bağlantılı kuvvette devamlıllk antrenmanlarının bazı fizyolojik ve fiziksel parametreler üzerine etkisinin incelenmesi. Gazi Üniversitesi Sağlık Bilimleri Enstitüsü Beden Eğitimi ve Spor Anabilim Dalı. Ankara, 2006.

Fernandez, J., Mendez-Villanueva, A., \& Pluim, B. M. (2006). Intensity of tennis match play. British Journal of Sports Medicine, 40(5), 387-391. https://doi.org/10.1136/bjsm.2005.023168

Fernandez-Fernandez, J., Mendez-Villanueva, A., Fernandez-Garcia, B., \& Terrados, N. (2007). Match activity and physiological responses during a junior female singles tennis tournament. British Journal of Sports Medicine, 41(11), 711-716. https://doi.org/10.1136/bjsm.2007.036210

Groppel, J., \& DiNubile, N. (2009). Tennis for the health of it. Phys Sportsmed, 37(2), 40-50. https://doi.org/10.3810/psm.2009.06.1708

Işıldak, K., \& Kumartaşl1, M. (2018). Effects of periodic training on anthropometric, physiological and bio-motoric development characteristics of elite swimmers in 12-15 age groups. European Journal of Physical Education and Sport Science, 4(4), 65-81.

Kilit, B., \& Arslan, E (2017). Tenis müsabakalarında fizyolojik gereksinimler. SPORMETRE Beden Eğitimi ve Spor Bilimleri Dergisi, 15(3), 157-164. https://doi.org/10.1501/Sporm_0000000320

Kızılakşam, E. (2006). Edirne il merkezi ilkögretim okullarındaki 12-14 yaş grubu aktif olarak spor yapan ve yapmayan (beden eğitimi dersine giren) öğrencilerin eurofit test bataryalart uygulama sonuçlarının karşılaştırılması. Trakya Üniversitesi Sağlık Bilimleri Enstitüsü Beden Eğitimi ve Spor Anabilim Dalı Yüksek Lisans Programı.

König, D., Huonker, M., Schmid, A., Halle, M., Berg, A., \& Keul, J. (2001). Cardiovascular, metabolic, and hormonal parameters in professional tennis players. Medicine and science in sports and exercise, 33(4), 654-658. https://doi.org/10.1097/00005768-200104000-00022

Kovacs, M. S. (2007). Applied Physiology of Tennis Performance. British Journal of Sports Medicine, 40, 381386. https://doi.org/10.1136/bjsm.2005.023309

Özcan, S. (2011). Temel tenis teknik öğretiminde iki farklı antrenman metodunun teknik biyomotorik ve fizyolojik özellikler üzerine etkisinin araştırılması. Süleyman Demirel Üniversitesi Sağlık Bilimleri Enstitüsü, Yüksek Lisans Tezi. Isparta.

Özdal, M., Önder, D., Tuncer, D., \& Nadide, Ö. (2014). Aerobik antrenmanın arteriyel hemoglobin oksijen satürasyonu üzerine etkisi. Spor ve Performans Araşstırmaları Dergisi, 5(1). https://doi.org/10.17155/spd.23139

Pate, R. R., Freedson, P. S., \& Sallıs, J. F. (2002). Compliance with physical activity guidelines:Prevalence in a population of children and youth. AEP, 12, 303-308. https://doi.org/10.1016/S1047-2797(01)00263-0

Reid, M., \& Schneiker, K. (2008). Strength and conditioning in tennis: current research and practice. Journal of Science and Medicine in Sport, 11(3), 248-256. https://doi.org/10.1016/j.jsams.2007.05.002

Reilly, T., \& Palmer, J. (1995). Investigation of exercise intensity in male singles lawn tennis. In T. Reilly, M. 
Hughes and A. Lees (Eds.), Science and Racket Sports (pp. 10-13).

Sarıtaş, N., Nakaç, A., Yazıcı, C., Büyükipekçi, S., \& Coşkun B. (2013). Effect of vitamin e on oxidant and antioxidant capacity in football players. Nigde University Journal of Physical Education and Sport Sciences, $7(2)$.

Smekal, G., Von Duvillard, S. P., Rihacek, C., Pokan, R., Hofmann, P., Baron, R.. \& Bachl, N. (2001). A physiological profile of tennis match play. Medicine \& Science in Sports \& Exercise, 33(6), 999-1005. https://doi.org/10.1097/00005768-200106000-00020

Suna, G., \& Kumartasli, M. (2017). Investigating aerobic, anaerobic combine technical trainings' effects on performance in tennis players. Universal Journal of Educational Research, 5(1), 113-120. https://doi.org/10.13189/ujer.2017.050114

Turna, B., Gençtürk, B., \& Bulduk, Y. (2019). An investigation of the effect of post-activation potentiation on some performance parameters in young male soccer players. Mediterranean Journal of Humanities, IX(1), 335-347. https://doi.org/10.13114/MJH.2019.467

Turna, B., Yavuz, S. C., Alp, M., \& Işıldak, K. (2017). Effects of interval sprint trainings on lactate level and heart rate. Journal of Human Sciences, 14(2), 1435-1440. https://doi.org/10.14687/jhs.v14i2.4530

Yıldız, H. (2007). Çabuk kuvvet çalı̧̧malarının 12-14 yas grubu masa tenisçilerin bazı motorik özelliklerine etkisi. Sakarya Üniversitesi Sosyal Bilimler Enstitüsü Yüksek Lisans Tezi, Sakarya.

\section{Copyrights}

Copyright for this article is retained by the author, with first publication rights granted to the journal.

This is an open-access article distributed under the terms and conditions of the Creative Commons Attribution license (http://creativecommons.org/licenses/by/4.0/). 